\title{
Influence on Explicit Grammar and Implicit Grammar Teaching for College English Learning
}

\author{
ZHENG Ling, ZHANG Quan-feng \\ Changchun University, Changchun, China
}

\begin{abstract}
At present, there are two kinds of different teaching methods for college English teaching, that is, the explicit grammar teaching method and implicit grammar teaching method. Explicit grammar teaching method and implicit grammar teaching method are not completely independent or mutually exclusive with each other. However, these two teaching systems are complementary with each other, and make mutual promotion for the other part, which does a great help in college English learning and teaching. The integration of two kinds of grammar teaching mode is helpful in making the students understand the syntax structure more profound, keep their memory last long, and improve the efficiency of the overall college English learning.
\end{abstract}

Keywords: college English, explicit grammar, implicit grammar, influence

\section{Introduction}

In the field of English teaching, grammar teaching is always being a controversial topic. With the application of listening and speaking teaching method, the opposition between explicit method and implicit method is becoming more and more obvious. At the same time, the authority of explicit grammar teaching method is represented by the traditional translation teaching method and the communicative language teaching has been shaken. And more scholars join the rank of supporting the implicit grammar teaching. Over now, there are still many controversial problems about these two teaching methods that deserve to be researched. Besides, the explicit grammar teaching method and explicit teaching method both have their own advantages and disadvantages. However, they are not contradictory in the practical application conditions.

\section{Basic Knowledge}

\section{Explicit Learning and Implicit Learning}

The concept of "explicit learning" and "implicit learning" was firstly proposed by Reber in 1967, based on a restricted state grammar experiment. Explicit learning refers to students' learning English knowledge (vocabulary, phonics, grammar) through the explicit means, such as memory and grammar analysis. This kind of English learning process is conscious, controllable, and with deformability. In addition, the learners have an acknowledgement of the elements that are contained in this process and have the ability of expressing the

ZHENG Ling, lecturer, master, Foreign Languages College, Changchun University.

ZHANG Quan-feng, lecturer, master, Foreign Languages College, Changchun University. 
knowledge managed by them. However, compared with the explicit learning, the implicit learning is unconscious. That is to say, the learners are unknown to the content that they are learning about. And what is more, they even do not aware they are in the state of learning something, which are not constructive and are verified.

Then, to make a conclusion, different from the explicit learning, the implicit learning has the characteristics of being automatic, abstractive, stable, and interference-free.

\section{Explicit Knowledge and Implicit Knowledge}

The explicit knowledge is the knowledge that plays a role in human being's lives and composes the learner's language. Simply speaking, explicit knowledge refers to the declarative knowledge about language and its application. From the definition that defined by Rod Ellis, it can be seen that the explicit knowledge is what people can learn consciously and can be also expressed. Contrary to what explicit knowledge is, implicit knowledge is what is managed unconsciously. It can be absorbed by learners without specific purpose, namely, the learners do not have the concept that they are learning or what they have learned about. Researchers declare that the implicit knowledge is acquired randomly, stored implicitly, and used automatically. For example, children' acquiring of their mother tongue is the process of implicit learning. They can master the characteristics and rules of their mother tongue in the unconscious state. For them, the mother tongue is the implicit knowledge.

\section{Explicit Grammar Teaching and Implicit Grammar Teaching in College English Learning}

\section{Explicit Grammar Teaching}

Explicit grammar teaching method refers to the fact that the learner master English grammar by studying the grammar rules. In this way, the teaching focuses on the grammar rules, which directly highlights the grammatical teaching purpose and the important role that the teacher plays in this process. In the collage students' explicit English classes, the teacher firstly presents or describes the English grammar structure or knowledge points. Then, the teacher makes the students practice what the teacher has presents or describes to them. Next, the students manage the new grammar points and try to pronounce correctly through imitation. Last, the teacher guides the students to make a practice of the new knowledge points in a contextual language environment. It can be seen that, in the explicit grammar teaching method, the English grammar is viewed as a complete knowledge system. And the learning goal is achieved by teachers' description systematically and the students' making practices consciously.

From the theory above, we can see that the practicing and training of the explicit grammar can help the students grasp the English grammar and memory them effectively. And for Chinese college students, English is a foreign language, instead of a second language, which means that the Chinese students lack the environment required by English learning. And the mastering of English is mainly achieved by mechanical training and practicing. Therefore, in this way, the college students should master the English grammar rules in order to understand the law of English grammar system and the characteristics of English.

\section{Implicit Grammar Teaching}

Implicit grammar teaching method avoids presenting or discussing the grammar rule to be learned directly. Otherwise, in the classes, English is mainly experienced by students through concrete scenes. Then the English grammar is summarized through students' using of English in communication, which emphasizes the role of 
students in this process. The implicit grammar teaching method stresses the environment of English learning. Only in the meaningful and understandable environment and scenes, can the learners acquired English grammar and knowledge points naturally.

The explicit grammar teaching method pays too much attention to the language form. And the teachers are dominant in the class, which leads to the situation that students try their best in making notes, imitating, and memorizing passively. Then the class is overwhelmed by students' practicing inflexibility, doctrinally, and in isolation. This kind of teaching is simple, without much changing. Thus, the English class is putting forward around the English grammar rules.

\section{The Influence of Explicit Grammar and Implicit Grammar Teaching on College English Learning}

\section{The Influence on College English Learning Efficiency}

Explicit grammar teaching is a system that makes the grammar knowledge more clearly, arouse the students' attention to master grammatical features, improve their awareness of the grammatical features, and let the students know the orderly of English grammar knowledge system. Explicit teaching can help learners to build explicit language knowledge. Explicit language knowledge refers to the learners' conscious of all knowledge that can clearly express of the target language. If learners master a large number of explicit language, it shows that they know many forms of the target language and the knowledge of the rules. The explicit language knowledge can be internalized through classroom learning practice. The ultimate goal of college English learning is to have the ability to communicate in English, to master a lot of implicit English knowledge, and to skilfully use English, so implicit knowledge of English is very important, but the explicit knowledge acquisition is the premise of all. Explicit grammar teaching greatly reduced the degree of participation of students, limited the learning ability of students; it is single grammar knowledge that will also make the classroom boring. Most of the college students have a low interest in English grammar learning. If the teacher only uses explicit grammar teaching method in college English teaching class, it will reduce students' enthusiasm of learn English grammar further.

Implicit grammar teaching can make the environment of college English learning easier, eliminate college students' fear of grammar learning psychology, enhance students' learning initiative, improve their ability to find and solve problems, and strengthen their confidence and English learning ability. At the same time, implicit grammar teaching that emphasis on large number of input context can be done in English listening, speaking, reading, and writing practice, greatly strengthen the college students' sensitivity of grammar structure, and improve their communicate ability. But students need to attend Practical English Test for Colleges and College English Test Band 4; one of these texts' main content is grammar. Therefore, in order to achieve good results in these tests, students must make an advantage of implicit grammar teaching, have a solid knowledge of English grammar, and understand and be able to use English grammar rules.

\section{The Influence on College English Learning Strategies}

The combination of explicit and implicit teaching can achieve better teaching effects, but the choice of English teaching method is related to teaching content, so is grammar teaching. In the process of college English learning, teacher should decide according to the difficulty of grammar to adopt the explicit or implicit grammar teaching method. For the grammar project that is similar with Chinese grammar structure or easy to master, 
students can use implicit grammar teaching method, such as the use of passive tense. Students can better master and use it with correct guide; there is no need to spend too much time on the boring pattern practice. For the grammar project, that is different from the Chinese grammatical structure or difficult for student to master, such as the use of present perfect tense, suitable for using explicit grammar teaching. With the teacher's detailed explanation and induction of the grammar project, students can understand and consolidate the contents of the English grammar knowledge.

Based on the explicit and implicit grammar teaching, college English learning strategy mainly includes: (1) display. Grammar is no longer isolated, monotonously appearing in front of the students, but will show students the grammar project that contains story, dialogue, articles, or situation, so as to guide students observe, understand, and take notice of the meaning and structure of the grammatical text. The material that college teachers display should be vivid; the teaching method should be diversified, such as slides or video, etc., so as to stimulate students' interest, guide students to actively participate in the teaching and learning activities; (2) interpretation. Separate the grammar structure from the context, do a detailed analyze, mainly explain the structure, meaning function, or use of rules of the grammar project. In the course of the explanation, teacher should under the specific language situation, make students be clear of the grammar structure; and (3) practice. After students fully understand the usage of grammar, teacher should provide a series of classroom practice, let student through control and semi-control and free use practice, and gradually master grammar project. The practice can be written, can be also oral English activities, but content must from the students' truly experience, point of view, emotion, and so on. In the real situation of communication, students can learn grammar knowledge by completing the communication tasks, acquiring grammar knowledge under the language communication rules, so as to easily learn grammar in the process of communication.

\section{Conclusion}

Explicit grammar can improve the college students' attention to language form, through a lot of sentence pattern training to make the students clearly remember the grammar project, but it stresses on grammar teaching forms too much, although it can let students make sentences with accurate grammar, it cannot use simple English in daily communication. However, the atmosphere of implicit grammar teaching class is relatively active; it can provide more interaction between teachers and students, through the interactive feedback let students output more efficient and more accurate. Therefore, the colleges and universities should make a combination of the explicit grammar teaching method and explicit teaching method in the practical English teaching courses, based on the actual teaching condition and the college students' characteristics.

\section{References}

De Keyser, R. (2003). Implicit and explicit learning. In C. Doughty and M. Long (Eds), Handbook of second language acquisition (pp. 313-348). Oxford: Blackwell.

Ellis, R. (2001). Introduction: Investigating from-focused instruction. Language Learning, 51(Supplement 1), 1-46. Littlewood, W. (2000). Communicative language teaching. Beijing: Foreign Language Teaching and Research Press. López, E. M. (2004). Implicit and explicit teaching of grammar: An empirical study. Teachers Professional Development, 5(1), 7-12. Norris, J. M., \& Ortega, L. (2001). Does type of instruction make a difference? Substantive findings from a meta-analytic review. In R. Ellis (Ed), From-focused instruction and second language learning (pp. 157-213). Oxford, UK: Blackwell Publisher.

Scott, V. M. (1989). An empirical study of explicit and implicit teaching strategies in French. The Modern Languages Journal, 73, 14-22. 